\title{
Editorial
}

\section{What future for the Europension?}

Europe has had a bad press in many areas: high unemployment, poor economic growth, conflicting strategic objectives. It has helped avoid another European war (mostly) and it is easier to move around and to have stuff moved around than it has been for over a hundred years.

But one area where it has seemed to make slow but steady growth has been in the field of pensions. Countries are learning from each other, it is possible to build up aggregated state pension rights in several member states, and now of course, (at least since September 2005) we have a European Pensions Directive, sometimes known as the IORP directive.

It has had an inauspicious birth. Around a decade previously a UK Commissioner, Sir Leon Brittan, convinced on rather spurious grounds that the pension systems comprised around 16 per cent of economic activity, called for a freeing up of national pension systems. He was determined that France, Germany and other countries which maintained restrictive investment and other practices were leading to a sclerosis of economic and labour activity.

And in many ways they were - as well as adding to costs. Few pension systems outside the UK, Ireland and the Netherlands were funded, contributing to capital formation. Most countries based even their second pillar systems on pay-as-you go arrangements, which had longer-term demographic instabilities, and which contributed to the poor capital formation in those jurisdictions. And where funded systems did exist, the assets had to be invested in ways which seem to modern eyes (at least Anglo-Saxon eyes) horribly constrictive. The investments were statutorily limited to government instruments, invariably bonds, and bonds issued by the country itself. This did not really fit into the concept of open markets that the EU was established to promote; it would have proved perverse when the Euro was invented - and it increased the cost of funded second-tier provision - certainly in comparison with systems backed largely by equity investments. EU figures suggested that pensions could have been higher (or costs lower) by a factor of 50 per cent if equity based investments had been permitted.

For the next ten years the draft documents struggled through the system. And in the end, by September 2003, a directive eventually emerged. It did indeed change the system. It set a framework for cross-border regulation (explored below). And it did, to an extent, remove some of the investment restrictions. It was reasonably short (certainly compared with UK legislation) and it looked reasonably straightforward.

But it did not quite do the entire job. It failed to produce the essential cross border tax reliefs. And it had been hijacked by the champions of regulation.

First the tax. Without cross-border tax 
relief, the notion of a single second-pillar pension system for multinationals (even if they wanted it) was a non-starter. Because of political constraints the directive itself is silent on tax - but its accompanying commentary urges member states to allow the reliefs required. In fact such exhortation is almost certainly unnecessary.

Cross-border tax relief has been imposed for several years now by the European Court of Justice in a series of well reported decisions such as Safir and Danner although member states have largely ignored it. As they may also do (1 June 2006) Case C-150/04, Commission des Communautés européennes v Royaume de Danemark (Manquement - Articles $39 \mathrm{CE}, 43 \mathrm{CE}$, $49 \mathrm{CE}$ et $56 \mathrm{CE}$ - Impôt sur le revenu - Prévoyance vieillesse — refus d'allègements fiscaux si les cotisations sont versées à des organismes de prévoyance vieillesse établis dans d'autres États membres - Justification pour des motifs tenant à la cohérence du système fiscal - Convention contre la double imposition; (not yet available in English)). A report by PricewaterhouseCoopers in March 2006 reported that Taxation and Customs Commissioner Laszlo Kovacs had declared that 'The European Commission is determined to tackle tax discrimination against occupational pension funds of other member states' — implying that several member states had not yet followed the requirements of the ECJ. The PwC study seems to make it clear that there are still major breaches by several leading member states.

And even within member states there are breaches of the World Bank recommended tax framework for pension systems: EET - exempt on pension contributions, exemption on pension investment growth and income, and taxation on benefits. The UK is a particularly unhelpful exemplar of a non-fit-for-purpose tax system for pension arrangements, although there are slight signs that the position might be about to improve.

The EU authorities continue to pursue member states for compliance in tax matters; but they also complain about inadequate compliance with the European Pensions Directive. Litigation is expected over the next year or so, but it is clear by the end of the decade, barring unforeseen tectonic changes in the European landscape, there will be a free market in pensions in the EU and the EEA - so that there will be a free choice for employers (in occupational arrangements) and other providers (in non-occupational arrangements) to decide where they would most like to register their schemes, to administer their schemes, and to invest their backing assets.

Once the freedoms not only emerge in theory but also in practice, member states will find themselves in competition to play host to pension systems. And a number of states have already announced that they wish to pitch for both multinational and domestic business. Austria now publishes its pensions legislation in English - as does Iceland. Luxembourg has made no secret of its ambition to play a major part in pan-European pensions operations, and Unilever has already established a modest cross-border operation there, although interest elsewhere has so far been limited, perhaps because of the complexity of the Luxemburgish legislation itself. Ireland has mentioned that it is entertaining a steady stream of visitors inquiring about the possibilities of Dublin based systems. As yet most of the information has been anecdotal, but unless matters change materially over the next few years, it seems all but inevitable that there will be a steady stream of such cases. 
The technical complexities should not be overlooked; even the Directive itself requires domestic compliance with social and labour law, requirements which are not yet fully understood. And one of the crevasses which has emerged is the apparent requirement that cross-border schemes must be better funded that single-jurisdiction-only schemes, which seems a curious reading of the legislation but one that appears to have acquired common currency. This particular trap seems to be able to be overcome by adjusting the terms of a scheme to avoid a formal DB promise, as some major Dutch schemes are presently doing with the agreement and consent of their unions, although there may be contractual issues in some cases. Assuming the traps can be avoided the advantages are material. First, in the UK at least, in which there would be no protection offered by the Pensions Protection Fund, there would be no need to pay a levy to the fund. This may not be a material issue for a well-funded system, but some major employers, even if their covenant seems strong, are significantly underfunded, and their levy contributions are high, in the tens of millions. Secondly, there would be no need to be possibly subject to additional calls by the UK Pensions Regulator if there is restructuring to try and constrain pension liabilities - or seek some form of clearance in such cases. So far it appears that the Regulator has had only relatively few such applications - but whether that is because employers have estimated it is not worth applying in many cases or whether there is truly little potential liability is as yet too early to conjecture. The general compliance requirements in relation to disputes, member representation and statutory trustee obligations would also be avoided. Finally the constraints on the kinds of
DB scheme that can be offered are limited under UK law, but not under other jurisdictions.

Finally, already discussed, there is the question of tax. The 3,500 pages of tax code in the UK are matched in practice by only a few (usually) sensible requirements in other jurisdictions, making the costs much lower - and offering the possibility of recovery of withholding taxes on equity dividends.

The move to exploit regulatory arbitrage will be slow initially; but once a couple of major names have taken the first steps, perhaps as a consequence of a cross-border joint venture, it is likely that there will be a small flood of requests. The impact on the UK will initially be modest; but once the reputation of being the automatic place to establish schemes is lost, investment, administration and other operations will also in time be transferred. The omens are good that the UK government has begun to recognise the counter-productiveness of its legislative framework but it will need some considerable work yet until the extraordinary construct of the last few years begins to fall away. In the meantime we, and everyone involved in pensions including the general public, should all be grateful for the competitive pressures that are being brought upon the UK regulators to take a pragmatic and sensible approach to the simple management of pension systems. The only danger now is that EU regulators, currently thinking of establishing a form of cartel of pensions regulators based in Frankfurt (see http://www.ebif.com/de/ kongress/downloads/downloadfiles/ CEIOPS-Programme2005.pdf) will re-invent a complexity of regulation which will all but lead to the reduction of interest of employers in the backing of schemes. The insurance industry is already marshalling its forces to try and restrict the operations of occupational 
pension schemes in the EU. Subject to fending off that attack and some others from fund managers, the chances are high that the EU directive, almost by mistake, will allow UK corporates and others to design and manage the kinds of schemes they and their employees would like to enjoy. Maybe the concept of Europe, at least as it applies to pension arrangements, will enjoy a better press in future years. 